\title{
QUALITY OF CORPORATE GOVERNANCE SYSTEM AND QUALITY OF REPORTED EARNINGS: EVIDENCE FROM CEE COMPANIES
}

\author{
Julia Bistrova ${ }^{1}$, Natalja Lace ${ }^{2}$ \\ ${ }^{1}$ Riga Technical University, Latvia, julija.bistrova@rtu.lv \\ ${ }^{2}$ Riga Technical University, Latvia,natalja.lace@rtu.lv \\ cross $^{\text {ref }}$ http://dx.doi.org/10.5755/j01.em.17.1.2251
}

\begin{abstract}
Previous research on Central and Eastern European countries showed that the lower is corporate governance quality the better is the firm's financial performance. One of the explanations for this phenomenon is that weak corporate governance is associated with the low earnings quality, which the present study looks into. The analysis, which was made on 118 companies quoted on Central and Eastern European stock exchanges, shows a prove to the negative relationship between the quality corporate governance and the level of accruals. The statistically significant results are based on the cash flow accruals, while balance sheet accruals, though showing a consistent pattern, do not provide significant evidence. Net income and operating cash flow discrepancy also detect lower than average earnings quality if a company has weak corporate governance system, while sufficiently good earnings plausibility in case of the well-managed companies.

Keywords: Corporate Governance, CEE countries, earnings plausibility, accrual accounting.

JEL Classification: G10, G32, G34, M41.
\end{abstract}

\section{Introduction}

Despite a number of legislative measures such as Sarbanes-Oxley Act, despite the negative past experience of the executives of the companies that have been cooking books, despite adverse effect on the company's operations and reputation that often led to bankruptcies, investors continue to face manipulation of financial figures, which companies do to cover losses and increase profits. Financial markets continue to be shaked by the corporate scandals, as a result of which investors often lose tangible amount of their investments in the listed companies. Most recent examples are Chinese Sino-Forest, when its largest investor, hedge fund Paulson \& Co, booked 462 million USD losses in less than a month, or Olympus, whose investors lost $81 \%$ in a month, when the illegal financial practices were discovered.

According to the previous research conducted by the authors (Grigorjeva \& Lace, 2008; Bistrova \& Lace 2011a), also the executives of the companies listed in the Baltic States have a strong temptation to use "creative accounting" practices to make the company look more attractive than it is in reality, which is very well seen in the IPO process. Though till now there was not any evidence of any public misstatement discovery or bankruptcy due to irresponsible accounting, sooner or later share price declines of the figuremanipulating companies, investors of which tend to lose as a result. The reason is that one cannot eternally hide the misstatement and soon the deterioration of the company's financial health comes in place, which turns into the loose stock performance. The timely detection of the accounting misstatements clearly improves stock portfolio performance in the emerging markets and developed markets (Dechow \& Dichev, 2001; Mahedy, 2005; Sloan, 1996; Grigorjeva \& Lace, 2008 etc.).

Multiple cases of the implausible financial reporting point to the necessity of conducting the earnings quality analysis as a part of fundamental analysis framework as no any auditor or sell-side analyst research can guarantee the quality of the published results. Though no party can make a guarantee of the result plausibility, the authors of the present study were still curious to know whether good corporate governance can be an indication of the improved financial reporting, lower accruals and better earnings quality.

Recent research revealed that good corporate governance helps to improve the stock performance (Bistrova \& Lace, 2011b). However, there is a negative correlation of the companies' stellar results and the quality of the corporate governance within the Central and Eastern Europe (CEE) stock universe (Bistrova \& Lace, 2012). Two major conclusions out of these studies are the following:

1.Financial results do not have a significant power to influence the stock performance of the companies, which was also proved in Baltic States before (Bistrova \& Lace, 2010);

2.There is a strong suspicion of the "financial shenanigans" used in the reports of the companies, which cannot boast of the strong corporate governance system.

Thus, the authors of the present study were willing to continue the research to clarify the situation regarding the quality of the accounting figures in the CEE companies and to put it into the context of the corporate governance quality. As both, corporate governance and earnings quality, tend to be two of the 
major factors for the company to demonstrate sustainable shareholder value and, therefore, sustainable shareholder return, the authors speculated that there should be a positive association between the quality of financials and quality of the corporate governance.

The authors proposed the following hypotheses to be checked in the course of the research:

Hypothesis I: Well-established corporate governance structure helps to ensure more rigorous discipline towards the financial reporting and, thus, ensures higher quality of the earnings management.

Hypothesis II: There is faster earnings quality improvement in the last three years of those companies, which demonstrate more solid corporate governance.

The main objective of the research would be to look into the quality of the corporate governance and the quality of earnings of the CEE companies and put these two determinants of the sustainable shareholder value creation in the relation to each other.

The research methods, which were employed to obtain the results, were the correlation analysis, regression analysis, quartile analysis as well as factor analysis.

The present study contributes to the academic literature by looking at the complex CG measure within the developing region, while most of the studies conducted till now focused mainly on the association of earnings quality and stand-alone characteristics of CG (Klein, 2002; Xie et al., 2003; Peasnell et al., 2005), whereas others focused on the developed equity markets (Larcker et al., 2007; Bowen et al., 2008; Jiang et al., 2008).

\section{Evidence of Association between Corporate Governance and Earnings Quality - Literature Review}

The literature dealing with the influence of corporate governance quality on the earnings management can be conditionally categorized into the two categories, one of which regards separate factors of the corporate governance, while the other looks into the complex measure of corporate governance, which includes a number of criteria to evaluate corporate governance structure.

\section{Attributes of Corporate Governance}

Less attention in this paper is paid to the separate attributes of CG system as the authors look into the complex evaluation, which considers 21 criterion on CG assessment. However, one cannot neglect them in order to have a complete picture of the research on the corporate governance connection to the quality of earnings.

The studies on financial reporting quality and board independence, which has strong influence on share price performance, provide mixed results. For example, Chin et al. (2006) states that there is a positive relationship between board size and earnings management, while the results of Xie et al. (2003) demonstrate the opposite results.

A number of studies indicate positive relationship between the quality of accounting and the strength of the audit committee governance, where the independence and the experience of the committee members are the key factors to achieve sustainable reporting (Dhaliwal et al. 2006, Baxter \& Cotter 2009, Choi et al., 2004). The results of the research on Malaysian companies by Hashim and Devi (2009) discover positive association between earnings quality and family ownership as well as concentrated institutional ownership. These two types of concentrated ownership structures are able to minimize the agency problem by establishing more efficient controlling procedures. Jiang \& Anandarajan (2009) also looked into the shareholding issues and discovered that the stronger are shareholder rights the better is the earnings quality.

\section{Corporate Governance Complex Measures}

Corporate Governance assessment indices, which allow to thoroughly evaluate corporate governance, have been developed rather recently. For example vastly used for academic research G-index was developed by Gompers et al. in 2003. Therefore, the majority of the studies on overall CG influence on quality of earnings management started to appear after 2006.

The researchers, which widely employed G-index for measuring corporate governance quality, came to the conclusion that there is no significant relationship between the corporate governance and earnings management (Bowen et al. 2008, Sivaramakrishnan \& Yu, 2008). But the authors of the latter study argue that not the strength but the adequacy of the corporate governance is a significant determinant of the earnings quality. Mentioned studies mainly focused on the US, covering large samples of US companies (over 3000).

The authors, who used other corporate governance assessment measures, were more successful to find the viable evidence that corporate governance is a determinant of the earnings management quality. For 
example, Jiang et al. (2008) applied Gov-score, which is comprised of 51 criteria and was developed by Brown and Caylor (2006). They found out that the higher is the quality of corporate governance the lower is accruals level and the better is earnings quality.

Larcker et al. (2007) assessed corporate governance using 39 criteria, which also included criteria on the capital structure characteristics. The study was conducted on 2106 companies quoted in USA. The researchers concluded that there is no strong indication that good CG improves the quality of earnings.

One of the most recent studies on CG was conducted by the Bekiris and Doukakis (2011), who used 55 criteria to evaluate the corporate governance quality of 427 Spanish and Greek firms. The main findings indicated that the strong corporate governance mechanisms increase the credibility of the financial reporting, which was clearly seen with large and mid-cap companies, while no evidence spotted with small capitalization companies.

Therefore, one can conclude that past research findings indicate that the quality of corporate governance can become a determinant of the quality of financial figures, although the ultimate association depends on the corporate governance metric chosen for the research.

\section{Research Methodology}

The main objective of the present study is to detect the relationship between the quality of corporate governance and the plausibility of earnings. Analyzed sample is comprised of 118 companies, which are included in the main lists of the CEE (Croatia, Czech Republic, Estonia, Hungary, Latvia, Lithuania, Romania, Poland, Slovakia, Slovenia) stock exchanges. The analysis period is 4 years (from 2007 to 2010), during which the influence of corporate governance on the plausibility of the financial results and its dynamics is evaluated. The data for the research purposes were extracted mainly from the corporate annual reports. Earnings quality was assessed based on the widely-accepted measures to detect creative accounting practices: level of accruals and comparison of net income level to operating cash flow.

The following formula has been used to determine the balance sheet based level of accruals for year $\mathrm{t}$ (Richardson \& Tuna, 2011):

$$
\text { Balance sheet based accruals }=\left(\mathrm{NOA}_{t}-\mathrm{NOA} t-1\right) /\left[\left(\mathrm{NOA}_{t}+\mathrm{NOA} t-1\right) / 2\right]
$$

where NOA is net operating assets, which are calculated in the following way:

$$
\text { NOA }=(\text { Total assetst }- \text { Casht })-(\text { Total liabilitiest }- \text { Total debtt }
$$

Another metrics of the accrual level, cash flow statement based accruals, was used to double-check the results for year t (Richardson \& Tuna, 2011):

Cash flow statement based accruals $=($ Net Incomet - Cash From Operationst - Cash From Investmentst $) /$ $\left(\left(\mathrm{NOA}_{t}+\mathrm{NOA} t-1\right) / 2\right)$

To make an evaluation of the CEE companies corporate governance organization, the authors employed the corporate governance assessment model, which was developed in 2011 and was tested on the CEE listed companies (Bistrova \& Lace 2011b). The model was developed based on the CG best practices recommended by the CEE stock exchanges. The model consists of 21 criteria which are grouped into 4 major categories: Supervisory Board, Management team, Investor Relations/AGM and Information Transparency. Corporate governance assessment was made based on the annual reports of FY 2009 as well as on the corporate governance reports and website information.

To detect the evidence of the statistically significant relationship between the plausible corporate governance and the plausible reported earnings, the authors ran a regression, where the dependent variable was accruals level and independent - corporate governance rating. Besides, the quartile analysis was used to visualize the results.

\section{Research Results}

\section{Earnings Quality of CEE companies}

The quality of earnings management provide the hint of the result plausibility and earnings level sustainability, which gains importance in such dynamic environment as Central and Eastern Europe. One of the simplest measures to test earnings quality is accruals level versus corporate assets determination. In the present paper the authors base their conclusions on the two methods to define accruals level - cash flow and 
balance sheet. There can be an insignificant difference between the results provided by the two methods due to non-cash acquisitions, currency translation etc. However, the correlation between the results provided by the two methods exceeds 80\% (Richardson \& Tuna, 2011).

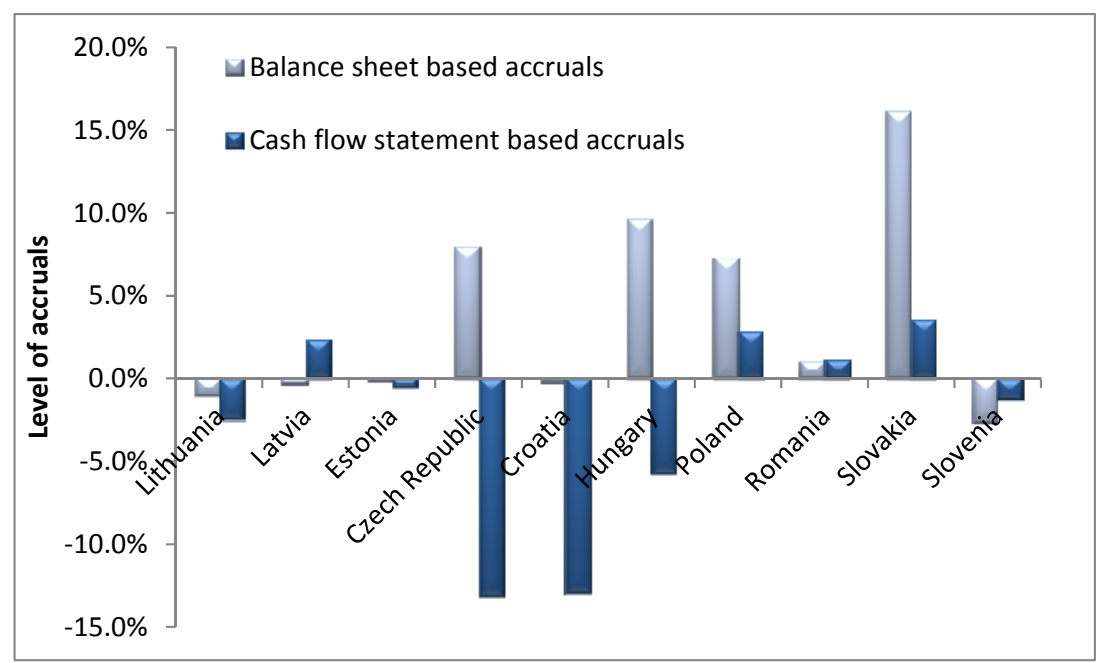

Figure 1. Median accrual levels of the companies listed on CEE stock exchanges (2007-2010)

According to the chart on Figure 1 the accruals are non-existent in the Baltic States (exc. Latvia), Croatia and Slovenia. Interestingly, that these regions got the highest CG ratings on the corporate governance in the previous study on CG evaluation (Bistrova \& Lace, 2011b). Romania, Slovakia and Hungary, which received not too high CG scores, also cannot boast of the perfect earnings quality as seen from the chart. In majority of cases cash flow statement and balance sheet accruals are not significantly different one from another. However, in some instances the difference becomes rather evident, which happens mainly due to insufficient number of companies, when it comes to the country level, and the results can be distorted by one or several companies.

Another measure of accounting quality is the determination of the discrepancy between the operating cash flow and the operating and net income. In the long-term operating cash flow and operating income should be equal, while in the short-term operating cash flow should be at least higher than net income.

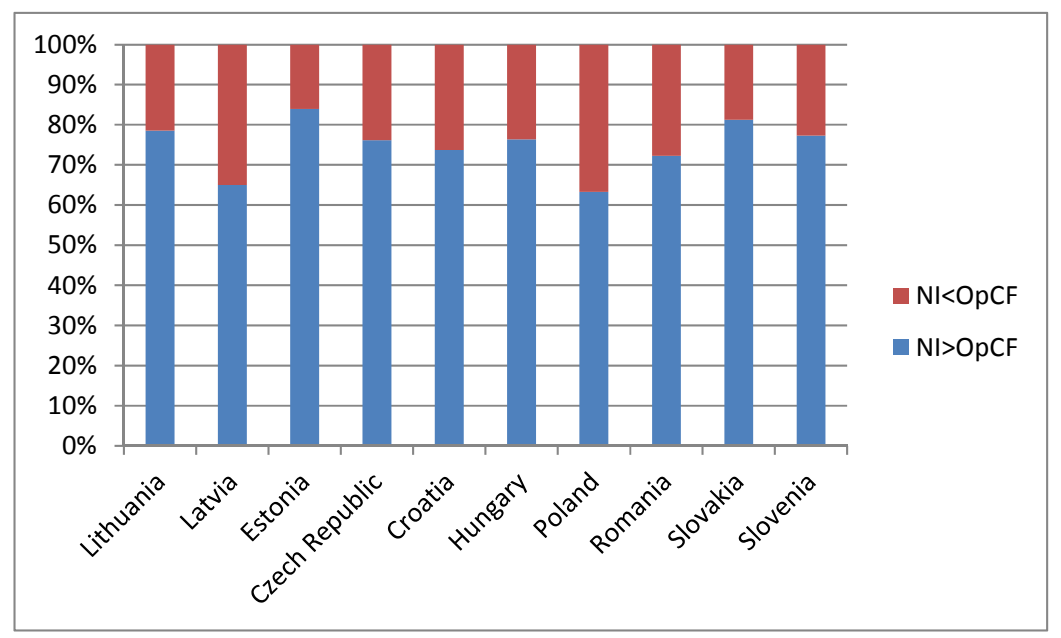

Figure 2. Proportionate number of cases when net income exceeded or fell behind operating cash flow (2007-2010)

Figure 2 shows in which countries there were more cases when the quality of earnings can be questioned, i.e. when net income exceeded operating cash flow, thus making the earnings unsustainable. Latvian, Polish and Romanian companies more often than average reported net incomes higher than the cash flow. While Estonian, Lithuanian and Slovakian companies provide more plausible results than their peers as they less often than average reported higher net income. 
Overall the situation with the accrual level within CEE stock universe is relatively good as the accruals for the market are on the low level and there is an improvement trend seen throughout the last four years. For example, sample median balance sheet based accruals declined from 3.8\% in 2007 to $-0.2 \%$ in 2010 and cash flow statement based accruals declined from $0.46 \%$ in 2007 to $-0.84 \%$ in 2010 . The lowest level of accruals, according to the both methods, was seen during the downcycle in 2009.

Corporate Governance Influence on Earnings Quality

To prove the first hypothesis on the CG influence significance, the authors ran the regressions, the results of which are reflected in the Table 1 .

Table 1. Key Regression Statistics ( $\mathrm{x}$ - CG rating, $\mathrm{y}$ - average accruals level)

\begin{tabular}{lcr}
\hline Regression Statistics & Balance sheet based accruals & Cash flow statement based accruals \\
\hline Multiple R & $8.2 \%$ & $19.6 \%$ \\
R Square & 0.0067 & 0.0385 \\
Coefficients & -0.0047 & -0.2013 \\
t Stat & -0.7830 & -1.7091 \\
F Stat & 0.6130 & 2.9209 \\
\hline
\end{tabular}

Several conclusions can be drawn out of the regression results. First, there is a negative association between the quality of corporate governance and level of accruals. Second, there is a moderate negative correlation of CG rating and the level of cash flow statement based accruals. Third, the regression based on the cash flow accruals shows significant relationship at $10 \%$ level, according to the t-test.

The quartile analysis was the next step to perform the analysis in order to be able to prove the hypothesis. The companies in the sample were divided into 4 equal parts (quartiles) according to their corporate governance rating, meaning that the first quartile is comprised of companies with the lowest CG ranking, while the fourth quartile is comprised solely of well-managed CEE companies.

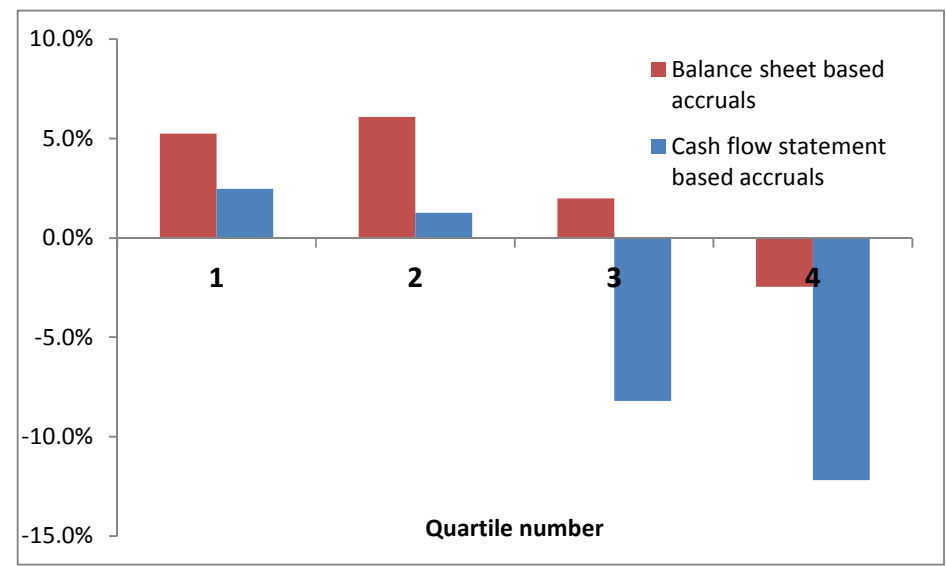

Figure 3. Median level of accruals (2007-2010) according to the CG quartile (1-worst CG, 4-best CG)

The main finding of the quartile analysis is that there is an association between financial reporting plausibility and how well corporate governance system is established and run. There is a clear pattern of the declining accruals when the corporate governance rating is increased, particularly well-seen in case of the cash flow based accruals.

However, the authors were not able to prove the second hypothesis that the companies, which are wellmanaged show fast improvement in the level of accruals than the companies with weaker CG systems. The results obtained were rather ambiguous to be able to make any robust conclusion. For example, in the case of cash flow accruals, the companies of the $2^{\text {nd }}$ and $3^{\text {rd }}$ quartiles showed the best improvement, while the companies with the best CG ratings were lagging behind all other quartiles. In the case of balance sheet accruals, the companies of the $1^{\text {st }}$ and $4^{\text {th }}$ quartiles did their best to rapidly improve the earnings management.

Considering another measure of the earnings quality, which is net income comparison to operating cash flow, the authors did not see as clear results as when considering accruals, but still a certain relationship can be spotted. 


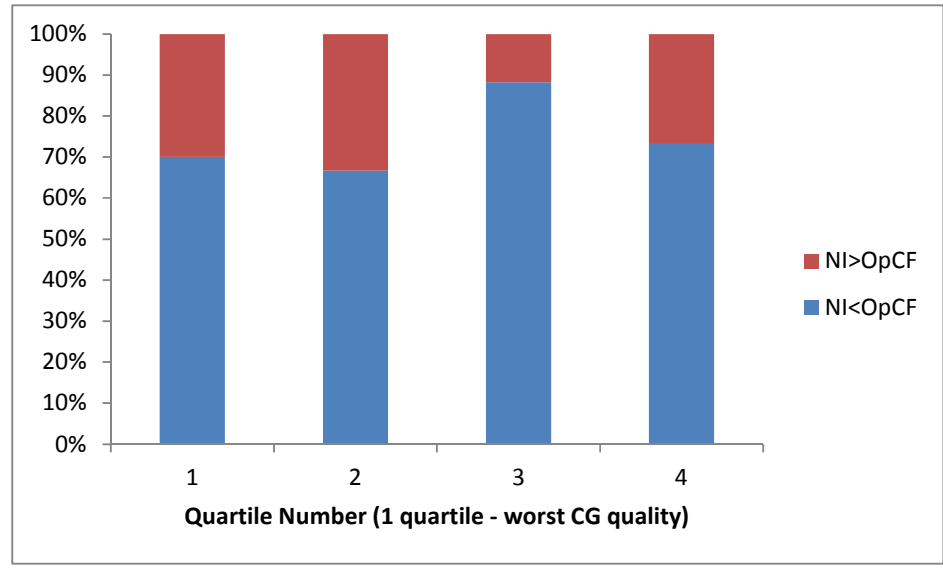

Figure 4. Proportionate number of cases when net income exceeded or fell behind operating cash flow according to CG quartile (2007-2010)

The number of cases when the net income exceeded operating cash flow, pointing the higher earnings plausibility, was the lowest in the case of the third quartile. It has been lower also in the fourth quartile, compared to the first or second quartiles. Therefore, the companies with above average corporate governance quality are able to offer above average earnings quality.

\section{Conclusions}

Two hypotheses were stated prior to conducting the research on the association between the corporate governance quality and the quality of the reporting earnings. The results obtained in the course of the study prove the first hypothesis that there is less risk to face financial results manipulation if the corporate governance is of the high quality, meaning that its board and management team act according to the best practice, information on the company is transparent and publicly available etc. The second hypothesis that well-managed companies are also the best in improving quality of the reported earnings during the last three years was not proved as the results of the study proved to be rather mixed.

The analysis of the overall earnings management in CEE region demonstrated that the situation is rather favourable for the CEE investors as earnings manipulation is on a rather low level, based on the accruals analysis and comparison of net income to operating cash flow. Besides, there is a strong trend for the results improvement during the last four years. Perhaps, partly it can be linked to the recent financial crisis, when the management had lower incentives to manipulate earnings due to the overall depression and also significant investment outflows from CEE companies.

When trying to discover the relationship between the corporate governance and quality of earnings, the authors used regression and quartile analyses, both of which showed the two variables negative relationship. When considering cash flow statement based accruals, the results become statistically significant and, thus, more reliable than in the case of balance sheet based accruals. Net income and operating cash flow comparison was also able to support the results by showing that the well-managed companies are providing more plausible results.

The present research completes the previous two studies on corporate governance (Bistrova \& Lace, 2011b; Bistrova \& Lace, 2012), which discovered positive association of CG and stock performance, while negative association of CG and firm's financial performance. The possible explanation of this phenomenon was "creative accounting”, as weak CG systems lack efficiency to control for earnings manipulation and, therefore, the companies post "inflated earnings", which are not sustainable in the long-run. The present study provides evidence that this explanation might be true, indeed, as the weakly governed companies more often tend to publish "financial shenanigans".

Therefore, the authors strongly recommend investors to include corporate governance analysis in the standard fundamental analysis framework as the quality of corporate governance can help to avoid “negative” earnings surprises.

\section{References}

1. Baxter, P. \& Cotter, J. (2009). Audit committees and earnings quality. Accounting and Finance, 49, 267-290. 
2. Bistrova, J. \& Lace, N. (2012) Corporate governance influence on firms’ financial performance in CEE countries. 7th International Scientific Conference Business and Management-2012, Vilnius, not published.

3. Bistrova, J. \& Lace, N. (2011a). Corporate Financial Strength Sustainability Post PO: Evidence from Baltic Equity Market. Journal of Economics and Management, 16, 1082-1088.

4. Bistrova, J. \& Lace, N. (2011b). Evaluation of Corporate Governance Influence on Stock Performance of CEE Companies. WMSCI 2011 Proceedings I, United States of America, Orlando, 19.-22. July, 2011, 59-64.

5. Bistrova, J. \& Lace, N. (2010). Created Value of Fundamental Analysis During Pre and Post Crisis Period on the Baltic Equity Market. RTU, Economics and Management, 20, 26-32.

6. Bowen, R., Rajgopal, S. \& Venkatachalam, M. (2008). Accounting discretion, corporate governance and firm performance. Contemporary Accounting Research, 25(2), 351-405.

7. Brown, L.D. \& Caylor, M.L. (2006). Corporate governance and firm valuation. Journal of Accounting and Public Policy, 25, 409-434.

8. Chin, K.., Firth, M. \& Rui, O. (2006). Earnings management, corporate governance, and the market performance of seasoned equity offerings. Journal of Contemporary Accounting and Economics, 2(1), 73-98.

9. Choi, J., Jeon, K. \& Park, J. (2004). The role of audit committees in decreasing earnings management: Korean evidence. International Journal of Accounting, Auditing and Performance Evaluation, 1, 37-60.

10. Dechow, P. \& Dichev, I. (2001). The Quality of Accruals and Earnings: The Role of Accrual Estimation Error. Stephen M. Ross School of Business/ Haas School of Business.

11. Dhaliwal, D., Naiker, V. \& Navissi, F. (2006). Audit committee financial expertise, corporate governance and accruals quality: an empirical analysis. Working Paper, University of Arizona, University of Auckland and Monash University.

12. Doukakis, L.C. \& Bekiris, F.V. (2011). Corporate Governance and Accruals Earnings Management. Management. Managerial and Decision Economics, 32, 439-456.

13. Gompers, P., Ishii, J. \& Metrick A. (2003). Corporate governance and equity prices. The Quarterly Journal of Economics, 118 (1), 107-155.

14. Grigorjeva, J. \& Lace, N. (2008). Evaluation of impact of financial result plausibility of Baltic State companies on equity performance. Economics and Management, 13, 115-120.

15. Hashim, H.A. \& Devi, S.S. (2009). Board characteristics, ownership structure and earnings quality: Malaysian evidence. In Mathew Tsamenyi, Shahzad Uddin (ed.) Corporate Governance in Less Developed and Emerging Economies (Research in Accounting in Emerging Economies 8), Emerald Group Publishing Limited, 97-123.

16. Jiang, W., Lee, P. \& Anandarajan, A. (2008). The association between corporate governance and earnings quality: further evidence using the GOV-Score. Advances in Accounting, incorporating Advances in International Accounting, 24, 191-201.

17. Jiang, W. \& Anandarajan, A. (2009). Shareholder rights, corporate governance and earnings quality: The influence of institutional investors. Managerial Auditing Journal, 24 (8), 767 - 791.

18. Klein, A. (2002). Audit committee, board of director characteristics and earnings management. Journal of Accounting and Economics, 33, 375-400.

19. Larcker, D.F. (2007). Corporate governance, accounting outcomes, and organizational performance. The Accounting Review, 82, 963-1008.

20. Mahedy, J. (2005) Taking Earnings Quality into Account: A Practitioner’s Research into Balance-Sheet Accruals. Retrieved December 3, 2011, from ttp://www.alliancebernstein.com/CmsObjectABD/PDF/Research_WhitePaper/R21500_BalanceSheetsAccruals_05 0509_JPM.pdf

21. Peasnell, K.V., Pope, P.F. \& Young, S. (2005). Board monitoring and earnings management: Do outside directors influence abnormal accruals? Journal of Business, Finance and Accounting, 32, 1311-1246.

22. Richardson S. \& Tuna I. (2011). Evaluating Financial Reporting Quality. Financial Reporting and Analysis, CFA Program Curriculum, 343-406.

23. Sloan, R. (1996). Do stock prices fully reflect information in accruals and cash flows about future earnings? Accounting Review, 71, 289 - 315.

24. Sivaramakrishnan, Sh. \& Yu, Sh. C. (2008). On the Association Between Corporate Governance and Earnings Quality. Working Paper at University of Houston.

25. Xie, B., Davidson, W.N. \& DaDalt, P.J. (2003). Earnings management and corporate governance: the role of the board and the audit committee. Journal of Corporate Finance, 9, 295-316. 